\title{
Assessment of selected risks in the process of the creation and preparation of a municipal territorial plan
}

\author{
J. Betáková ${ }^{1}$, R. Zeman ${ }^{1}$, J. Dvorský ${ }^{2} \&$ T. Pavlenko ${ }^{2}$ \\ ${ }^{I}$ The Institute of Technology and Business in České Budejovice, \\ Czech Republic \\ ${ }^{2}$ Faculty of Security Engineering, The University of Žilina, Slovakia
}

\begin{abstract}
A territorial plan not only resolves the complex spatial arrangement and functional use of a territory but also creates the prerequisites for the permanently sustainable development of a municipality. Activities involved in territorial planning such as preparation, processing, discussion and approval of the territorial plan, have associated risks which can significantly impact on the quality of life of residents. A process of risk assessment and the subsequent incorporation thereof into strategic documents on territorial management can provide increased security for the territorial unit. On the basis of a survey possible risks are identified and assessed using a method of mathematical statistics known as "analysis of variance" (ANOVA). The risks are identified by determining the margins of acceptability using the "scoring method" in combination with a risk map. On the basis of the analysis the resulting risks are divided into acceptable and unacceptable risks. For unacceptable risks it is necessary to approve and incorporate preventive measures directly into the municipality's territorial planning documentation.
\end{abstract}

Keywords: assessment, risk, risk management, testing, territorial plan.

\section{Spatial planning documentation as a tool for sustainable community development}

Sustainable development means a targeted, long-term and complex process which affects all aspects of life (cultural, social, economic and environmental), at 
all levels (local, regional, global), within a community (city, region, country, international community) that meets the material, social needs and interests of its people. At the same time, it eliminates or significantly reduces interventions, threats, damage or destruction to those aspects of life or life itself by seeking to increase the safety of citizens, through the reasonable use of its resources and the protection of cultural and natural heritage [1].

In 2000, the National Council of the Slovak Republic for the first time enacted a definition of territorial development. It defined it as being development that sustainably satisfies the basic needs of the people of the country. Under conditions of declining biodiversity it must also guarantee optimal spatial arrangements and functional land use while maintaining environmental safety. This includes the durability of buildings and equipment, the creation and preservation of territorial systems for ecological stability, the economical use of natural resources and the protection of the nation's natural and cultural heritage [2].

Land use planning is an essential tool of State environmental policy. As a tool it systematically and comprehensively addresses spatial arrangements and functional land use. It also determines the principles by which this is done and coordinates the proposal of substantive and temporal activities which affect the environment, ecological stability and cultural values of the area, including territorial development and the landscape [3].

Table 1: Hierarchy of official bodies responsible for spatial planning in the Slovak Republic.

\begin{tabular}{|c|c|c|c|c|}
\hline \multicolumn{3}{|c|}{ Administrative structures and processes } & \multirow{2}{*}{$\begin{array}{l}\text { Planning } \\
\text { level }\end{array}$} & \multirow[t]{2}{*}{ Planning tool } \\
\hline Procurer & $\begin{array}{l}\text { Approval } \\
\text { authority }\end{array}$ & $\begin{array}{c}\text { Assessment } \\
\text { body }\end{array}$ & & \\
\hline MTCRD $^{*}$ & $\begin{array}{l}\text { Government } \\
\text { of SR }\end{array}$ & & State & $\begin{array}{l}\text { Urban development } \\
\text { concept of SR }\end{array}$ \\
\hline $\begin{array}{l}\text { Autonomous } \\
\text { region }\end{array}$ & $\begin{array}{l}\text { Autonomous } \\
\text { region }\end{array}$ & MTCRD $^{*}$ & Region & $\begin{array}{l}\text { Regional spatial } \\
\text { plan }\end{array}$ \\
\hline \multirow{2}{*}{ Municipality } & \multirow{2}{*}{$\begin{array}{l}\text { Municipal } \\
\text { council }\end{array}$} & \multirow{2}{*}{$\begin{array}{l}\text { District } \\
\text { authority }\end{array}$} & $\begin{array}{l}\text { Cadastral } \\
\text { area }\end{array}$ & $\begin{array}{l}\text { Municipal spatial } \\
\text { plan }\end{array}$ \\
\hline & & & Zone & Zone spatial plan \\
\hline
\end{tabular}

"MTCRD - Ministry of transport, construction and regional development

Spatial planning is based on the integration of knowledge of several disciplines (philosophy, sociology, history, archaeology, ethnography, architectural and local planning, ecology and other natural sciences). Where relevant, both civic organizations and NGOs alike should be involved in the spatial planning process [4]. Under the prevailing conditions, the task is to ensure the optimal use of land, sound financing, processing and the application of 
spatial planning documentation which reflects the demands of all stakeholders (architects, economists, sociologists, environmentalists, investors, and especially citizens). This often includes the resolution of long-term unresolved land ownership issues [5].

In order to comprehensively address the spatial arrangements and functional use of land, spatial planning documentation must reconcile the interests and activities which affect land development, the environment and ecological stability. In the Slovak Republic responsibility for this lies at different levels - at State, regional and municipal level and their official administrative bodies [6].

The process of preparing a spatial plan (SPN) or land planning documentation (LPD) consists of following steps:

- proposal put forward for community SPN;

- $\quad$ selection of qualified persons for preparation of LPD;

- $\quad$ preparatory work;

- $\quad$ selection of a person in charge of processing $\mathrm{PD}$;

- $\quad$ surveys and analyses;

- discussions;
- concept;

- opinion of the contracting authority;

- proposal for community SPN put forward;

- $\quad$ public hearing on SPN proposal;

- further consideration of SPN proposal;

- approval of municipal SPN.

\section{Survey methodology and the application of "analysis of variance" to assess risks in the process of municipal zoning plans}

This study focuses on the risks that may arise in the process of preparing and implementing spatial planning documentation for a community. The identified risks in the Slovak Republic were assessed by competent representatives in local planning authorities or communities. The aim of this research is to analyse selected risks associated with the development of zoning plans in municipalities of the Slovak Republic according to population size - small communities with up to 1000 inhabitants; medium-sized communities with 1000-2000 inhabitants; and larger communities with over 2000 inhabitants. Each group had a representative number of respondents (40) from persons responsible for spatial planning.

The basic framework for examining the issue forms a bond between the continuity of land development and actual potential use of land in a territorial area. Part of the objective of the survey was to identify unacceptable risks and their potential adverse effects on the quality of life and value systems of individual citizens.

For the analysis logical research and comparative methods are applied. The analytic-synthetic method was used for examining the various instruments of 
spatial management. The methods of induction and deduction were applied for the formulation of the conclusions. The basis of the research methodology assumes the principle of multi-level comprehensive analysis of selected activities and factors influencing the development of settlement structures. The actual processing is divided into three developmental stages:

- analysis of theoretical knowledge and practical experience compatible with the implementation of selected spatial management tools and their impact on the spatial development of settlement structures;

- analysis, quantification and the use of qualitative methods in the evaluation of selected risks in the process of acquiring land planning documentation in the context of sustainable development and planning mechanisms;

- summarizing conclusions for the practical application of the progressive approach to the assessment of settlement development potential.

A comprehensive survey was conducted within the framework of the project KEGA No. 005 DTI-4-2014 Sectorial integration of spatial impacts of the safety management of environmental risks. The research sample included 120 respondents. The respondents were those people responsible for local planning in the municipalities of the Trencin region in the Slovak Republic. The research was conducted between March and June 2015. Data collection was conducted through an electronic on-line survey and a standardized written questionnaire. The use of a questionnaire is an exploratory method of primary data collection. The procedure for the online survey was as follows:

- questionnaire in its final form was programmed into web format and placed on the internet and social networks for testing;

- after successful testing respondents were sent an email with a link to the survey and credentials;

- once the sample size and quotas had been met data collection was concluded (the advantage of online surveys is that it is possible to generate information at any time on the state of the research, repletion of quotas or statistics);

- collected data were checked for consistency, reliability and logical continuity of answers. Wrong answers (interviews) were excluded. The opinion of the respondents to the statistical characteristics was later added to the data and subsequently processed in a statistical program.

It is possible to determine the level of risk for those selected risks perceived by those responsible for spatial planning in municipalities, compared by population size, using an analysis of variance. Those responsible for spatial planning assessed the selected risks on the basis of the likelihood of them happening on a scale of 1-10. The lowest risk and the smallest overall damage was expressed by the number 1 . The largest risk and damage was expressed by the number 10. The term damage is understood to mean the sum of the direct damages (the duration of use of the land according to the land-use plan) and indirect damages (e.g. depopulation in larger municipalities). The processing of 
the mathematical method of "analysis of variance" is numerically intensive and was therefore carried out with the support of the statistical software Statgraphics Centurion XVII [7].

The most frequently identified risks associated with the process of preparing and implementing land-use planning documentation for municipalities, as indicated by the respondents from land-use planning authorities in the Slovak Republic, are:

1. financial risk - lack of financial resources;

2. procurement risk - difficulty in selecting a competent person for the preparation of land planning documentation for municipalities;

3. professional risk - inadequate skills of professionals in preparing land-use planning documentation;

4. time risk - in terms of how long it takes to generate land-use planning, planning and other relevant documents;

5. interest risk - interconnection between political and interest groups and their interests in the functional use of the territory of municipalities;

6. administrative risks - procedural, project and administrative errors during the process of preparing territorial planning documents;

7. personnel risk - staffing issues and unqualified persons responsible for land-use planning departments.

The application of the mathematical and statistical method of "analysis of variance" [8] consists of the following stages:

- $\quad$ calculation of selected risk characteristics (mean, variance) on the basis of the primary data collected through the survey of municipalities within SR;

- determination of suitability of the identified risks for parametric or nonparametric testing of the analysis of variance, given the conditions imposed on their implementation;

- testing of the variance rate for the risks identified according to the criteria of population size, using the parametric F-test and the nonparametric Kruskall-Wallis test;

- determination of whether the mean rate of the identified risks in the process of spatial planning are comparable according to the selected criteria.

\section{Analysis of variance for selected risks identified by spatial planning authorities}

Šimák states that the mathematical expression of risk is carried out through the measurement of risk, which is the product of the likelihood and possible range of the consequences $[9,10]$. The basic selective characteristics that are necessary for carrying out the mathematical method of "analysis of variance" [11] were 
calculated on the basis of the results from the assessment of those responsible for spatial planning. The results are given in Table 2, whereby:

$\mu \quad$ mean value of the selected risk as assessed by the competent persons for municipal land-use planning;

$\sigma^{2} \quad$ variance of the selected risk as assessed by the competent persons for municipal land-use planning.

Table 2: Basic selective characteristics for the selected risks.

\begin{tabular}{|c|c|c|c|c|c|c|}
\hline \multirow{2}{*}{$\begin{array}{c}\text { Selected } \\
\text { risk }\end{array}$} & \multicolumn{2}{|c|}{$\begin{array}{c}\text { Municipalities with } \\
\mathbf{2 0 0 1} \text { inhabitants }\end{array}$} & \multicolumn{2}{c|}{$\begin{array}{c}\text { Municipalities with } \\
\mathbf{1 0 0 1 - 2 0 0 0} \\
\text { inhabitants }\end{array}$} & \multicolumn{2}{|c|}{$\begin{array}{c}\text { Municipalities with } \\
\leq \mathbf{1 0 0 0} \text { inhabitants }\end{array}$} \\
\cline { 2 - 7 } & $\mu$ & $\sigma^{2}$ & $\mu$ & $\sigma^{2}$ & $\mu$ & $\sigma^{2}$ \\
\hline 1. & 87.84 & 14.15 & 86.19 & 11.17 & 91.66 & 16.02 \\
\hline 2. & 44.42 & 9.02 & 39.71 & 7.08 & 37.41 & 14.97 \\
\hline 3. & 76.64 & 8.79 & 71.97 & 6.54 & 79.81 & 16.94 \\
\hline 4. & 81.91 & 7.84 & 80.89 & 9.17 & 85.17 & 10.45 \\
\hline $\mathbf{5 .}$ & 28.74 & 4.46 & 30.77 & 7.88 & 31.51 & 6.79 \\
\hline $\mathbf{6 .}$ & 42.71 & 7.81 & 29.81 & 6.72 & 40.28 & 8.14 \\
\hline $\mathbf{7 .}$ & 25.74 & 5.45 & 21.20 & 10.81 & 23.98 & 11.92 \\
\hline
\end{tabular}

From the above it can be seen that the risk associated with insufficient funds is the most significant problem the people in charge of spatial planning face across all three groups. The main arguments are low budgets or no funds at all. For this risk we assume that the extent of the risk is therefore homogeneous. This homogenity is based on the risk levels associated with: the insufficient capability of those involved in the preparation of land-use planning documentation; procedural, project and administrative errors in the preparation process of landuse planning documentation; unqualified staff responsible for spatial planning. The statistical hypotheses will be verified using statistical tests. For the purposes of testing the mean values of a risk in the subject groups, in accordance with the criterion population size, we applied the parametric F-test or the non-parametric Kruskall-Wallis test. The appropriateness of applying the parametric test depends on two basic conditions being met:

- homoscedasticity - identification of variance of the identified risks (see Table 3);

- normal distribution - extent of the consequences of an identified risk (see Table 4).

The non-parametric Kruskall-Wallis test was applied when homoscedasticity variance was present, and where the extent of the consequences of the risk, when presented in a probabilistic model, did not have a normal distribution. 
Table 3: Bartlett's test to verify homoscedasticity rate of the identified risks.

\begin{tabular}{|c|c|}
\hline Selected risk & $\begin{array}{c}\text { Bartlett test } \\
\text { (p-value) }\end{array}$ \\
\hline $\mathbf{1 .}$ & 0.257 \\
\hline $\mathbf{2 .}$ & 0.146 \\
\hline $\mathbf{3 .}$ & 0.309 \\
\hline $\mathbf{4 .}$ & 0.094 \\
\hline $\mathbf{5 .}$ & 0.161 \\
\hline $\mathbf{6 .}$ & 0.639 \\
\hline $\mathbf{7 .}$ & 0.801 \\
\hline
\end{tabular}

Table 4: Pearson $\mathrm{x}^{2}$ test to verify normal distribution of the identified risks.

\begin{tabular}{|c|c|}
\hline Selected risks & $\begin{array}{c}\text { Pearsonov } \mathbf{x}^{\mathbf{2}} \text {-test } \\
\text { (p-value) }\end{array}$ \\
\hline 1. & 0.401 \\
\hline 2. & 0.007 \\
\hline 3. & 0.089 \\
\hline 4. & 0.048 \\
\hline $\mathbf{5 .}$ & 0.016 \\
\hline 6. & 0.382 \\
\hline 7. & 0.213 \\
\hline
\end{tabular}

The results of Bartlett's test indicate that with 0.95 probability the presumption of identical rate variances for the selected risks, as identified by those responsible for spatial planning in municipalities across the Slovak Republic, was accurate. The results of Pearson $x^{2}$ test shows that at a significance level of 0.05 some of the risks met all preconditions for performing a parametric F-test e.g. financial (1), professional (3), administrative (6) and personnel (7). In contrast, the p-value of the remaining identified risks fell below the significance level of 0.05 i.e. procurement (2), time (4), interest (5). The assumption that the identical variance rates for the identified risks was therefore inaccurate. The latter risks therefore fulfilled the preconditions for performing the nonparametric Kruskall-Wallis test. The results of the subsequent parametric and non-parametric tests are given in Tables 5 and 6 .

From the results of analysis of variance of the risks identified in the preparation process we can state that homogeneity has been proven with $95 \%$ reliability for the financial, professional and time risks i.e. the evaluation of the risks by those responsible for land-use planning in municipalities in all three groups was comparable. 
Table 5: Parametric F-test for identified risks in the preparation process of land-use documentation.

\begin{tabular}{|c|c|}
\hline Selected risk & $\begin{array}{c}\text { F-test } \\
\text { (p-value) }\end{array}$ \\
\hline 1. & 0.117 \\
\hline 3. & 0.339 \\
\hline 6. & 0.027 \\
\hline 7. & 0.015 \\
\hline
\end{tabular}

Table 6: Non-parametric Kruskall-Wallis test in the preparation process of land-use documentation.

\begin{tabular}{|c|c|}
\hline Selected risk & $\begin{array}{c}\text { Kruskall-Wallis test } \\
\text { (p-value) }\end{array}$ \\
\hline 2. & 0.026 \\
\hline 4. & 0.306 \\
\hline $\mathbf{5 .}$ & 0.004 \\
\hline
\end{tabular}

In the statistically representative sample there are no statistically significant differences between the assessments of the risks identified in the survey questionnaire. For other identified risks, at a significance level of 0.05 , there are no statistically significant differences in their evaluation. The perception of these risks is different and depends on the size of the municipality.

\section{Expert risk assessment by "scoring method with a risk map"}

The identified risks that may arise and influence the preparation process of spatial planning documentation were evaluated by the municipalities and the competent representatives through the conducted survey. The representatives directly affect the given issue in particular communities. The risks were then rated by the "scoring method with a risk map". A scoreboard of the identified risks was created consisting of the probability and the consequences of the risks. The values are the result of the averages of all the ratings given by the competent people. The results are given in Table 7.

On the basis of the data in Table 7 a map of risks can be generated (see Figure 1) which shows the coordinates of risk subject to the value of their probability and consequence. 
Table 7: The average value of the identified risks based on the evaluation of the competent spatial planning authorities.

\begin{tabular}{|c|c|c|}
\hline Identified risk & $\begin{array}{c}\text { Probability origin } \\
(\mathbf{1 - 1 0 )}\end{array}$ & $\begin{array}{c}\text { Risk consequence } \\
(\mathbf{1 - 1 0 )}\end{array}$ \\
\hline $\mathbf{1 .}$ & 8.5 & 9.08 \\
\hline $\mathbf{2 .}$ & 4.5 & 5.1 \\
\hline $\mathbf{3 .}$ & 6.9 & 7.4 \\
\hline $\mathbf{4 .}$ & 8.6 & 8.2 \\
\hline $\mathbf{5 .}$ & 3.6 & 4.8 \\
\hline $\mathbf{6 .}$ & 5.3 & 4.2 \\
\hline $\mathbf{7 .}$ & 4.4 & 3.4 \\
\hline
\end{tabular}

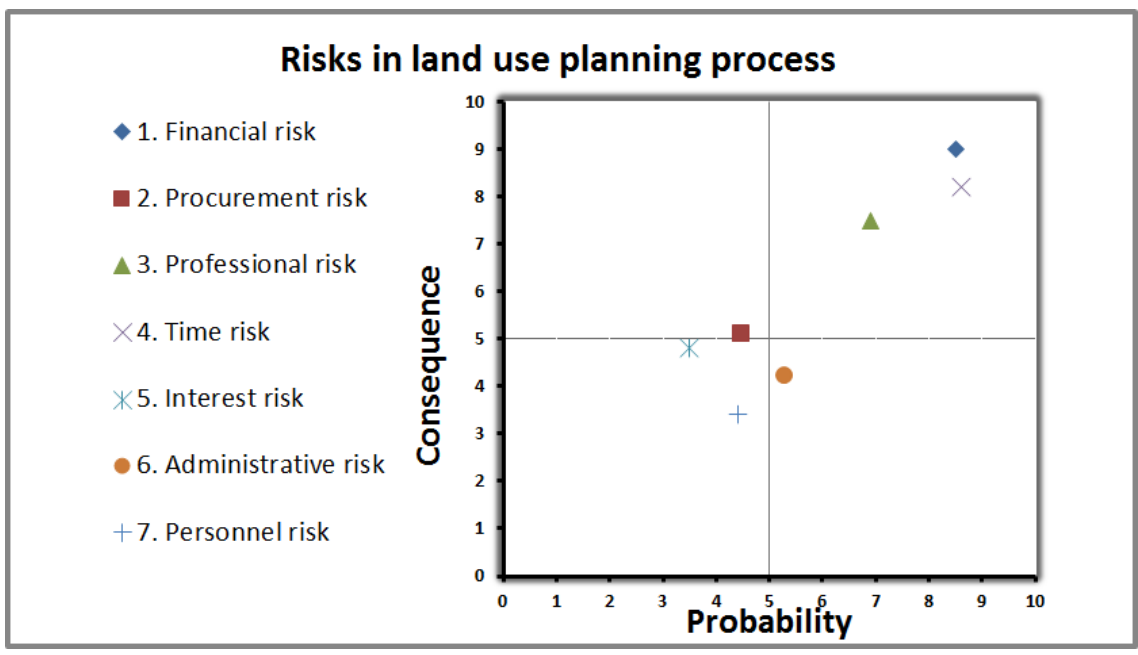

Figure 1: Risk map.

The risk map is divided into four equal quadrants. The risks contained in the first quadrant are of no significance and require no further action. However, the risks in the third and fourth quadrants are considered to be significant and critical respectively. These risks are unacceptable and therefore require serious attention. As is indicated in the figure, beyond finance the major risks relate to adequate skills and time. These risks require the development of specific preventive measures and proposals to eliminate them. By putting forward and implementing effective measures, the likelihood that the identified risk occurs will be reduced and the consequences thereof will be eliminated. This will ultimately lead to an increase in the quality of life of residents in the selected municipality. 


\section{Conclusion}

The process of creating a zoning plan is a significant document. It not only provides guidance on the current and future use of municipal space, but it also creates the conditions for the continuous improvement in the quality of life of it is residents. Quality of life in this context is understood to be broad and interdisciplinary in nature, whereby it includes critical elements of infrastructure, the demographics of the population and the civil and material safety of citizens. This paper, on the basis of a survey of persons responsible for spatial planning in municipalities, has sought to identify risks to the creation and preparation process. The consequences of those risks, which may have a negative impact on the processes, were also identified. By using the mathematical method of the analysis of variance, we came to the conclusion that the greatest threats in all the groups of municipalities, based on population size, were finances, time and skills. These results were later confirmed by the scoring method with a risk map. The risk map identified precisely these three risks as unacceptable. To effectively deal with these risks it is necessary to take preventive measures. A systematic and logical method therefore needs to be implemented whilst creating spatial plans for the identification of risks, risk analysis, risk management and the suggestion of measures for their elimination.

\section{Acknowledgements}

This work was carried out under the grant project - KEGA Project 005 DTI4/2014. The authors would like to thank the Ministry of Education of the Slovak Republic and the Faculty of Security Engineering, University of Zilina for their support.

\section{References}

[1] CEC 2007. Leipzig Charter on Sustainable European Cities, Council of Ministers, Leipzig.

[2] FINKA, M., Priestorové plánovanie. Bratislava, ISBN 978-80-88999-39-3, p. 235, 2011.

[3] Betáková, J., Dvorský, J. \& Havierniková K. Social capital and safety perception as aspect of improving regional competitiveness of territory. 2nd International Conference on Management Innovation and Business Innovation, Bangkok. ISBN 978-981-09-1685-5, pp. 68-73, 2014.

[4] Farazmand, A. Crisis and Emergency management. In CRC Press, Taylor \& Francis Group, U.S. ISBN 978-1-4200-1367-2, p. 793, 2014.

[5] Betáková, J., Dvorský, J. \& Pavlenko, T. Analýza rozptylu produkcie nebezpečného odpadu v Slovenskej republike. Ochrana obyvatel'stva Nebezpečné látky, Ostrava, ISBN 978-80-7385-158-3, pp. 3-6, 2015.

[6] Larsson, G. Spatial Planning Systems in Western Europe. In IOS Press, Amsterdam, ISBN 1-58603-656-4, p. 267, 2006. 
[7] Statgraphics: Software Statgraphics Centurion XVII. 2014. (Online). (Cit. 10 May 2015). Available: http://info.statgraphics.com/statgraphics-home.

[8] Betáková, J., Lorko, M. \& Dvorský J. The impact of the potential risks of the implementation of instruments for environmental area management on the development of urban settlements, Environmental impact II, Ancona, ISBN 978-184564762-9, pp. 91-101, 2014.

[9] Šimák, L. 2006. Manažment rizík. Žilina, 2006. (Online). (Cit. 8 May 2015). Dostupné na: http://fbi.uniza.sk/kkm/stranka/publikacna-cinnost.

[10] Havierniková, K., \& Skrovnaliková, P., The immunity of family business in the conditions of economic crisis, 2014. In: Problems of social and economic development of business: Collection of scientific articles. Volume I. - Montreal: Publishing house Breeze. ISBN 978-1-926711-195. pp. 179-183, 2014.

[11] Betáková, J., Lorko, M., \& Dvorský J., Sectional integration of spatial impacts of environmental risks. $6^{\text {th }}$ International Conference on Safety and Security Engineering, Opatija, Croatia, ISBN 978-1-84564-928-9, pp. 1526, 2015. 